Transition Management: Conceptual framework and Dutch implementation

\title{
A model for sustainability policy
}

\author{
Um Fortschritte auf dem Weg zur Nachhaltigkeit zu machen, verfolgen \\ niederländische Politiker Transitionsmanagement als neve Strategie. \\ Transitionsmanagement ist ein zukunftsorientiertes, reflexives Steuerungs- \\ modell für langfristige Transformationsprozesse unter Einbezug vieler Akteure. \\ An Leitbildern orientiert, schafft es eine Vielfalt von Optionen, gestaltet neve \\ Pfade und versucht, bestehende Rahmenbedingungen und Regimes auf reflexive \\ Weise anzupassen. Dies wird am Beispiel des laufenden niederländischen \\ Transitionsprozesses im Bereich Energie illustriert.
}

$\mathrm{I}$ 2001, five Dutch ministries adopted the new governance approach of transition management (1). According to the government, a different approach was needed to deal with persistent problems such as loss of biodiversity, climate change, depletion and overexploitation of natural resources, as well as future risks. The solution to these problems was believed to lie in transformations involving system innovation. The process of change from the existing system to a new one is called a transition, a term that became central to government thinking

In the sociotechnical realm, a transition may be defined as ,a gradual process of societal change in which society or an important subsystem of society structurally changes" (2). Transitions are the result of developments in various domains that sustain each other: technology, economy, institutions, behaviour, culture, ecology, and images as well as paradigms. Although transitions are characterised by non-linear behaviour, the process itself is a gradual one, typically spanning one or two generations or 25 to 50 years. A transition is believed to consist of four stages (3):

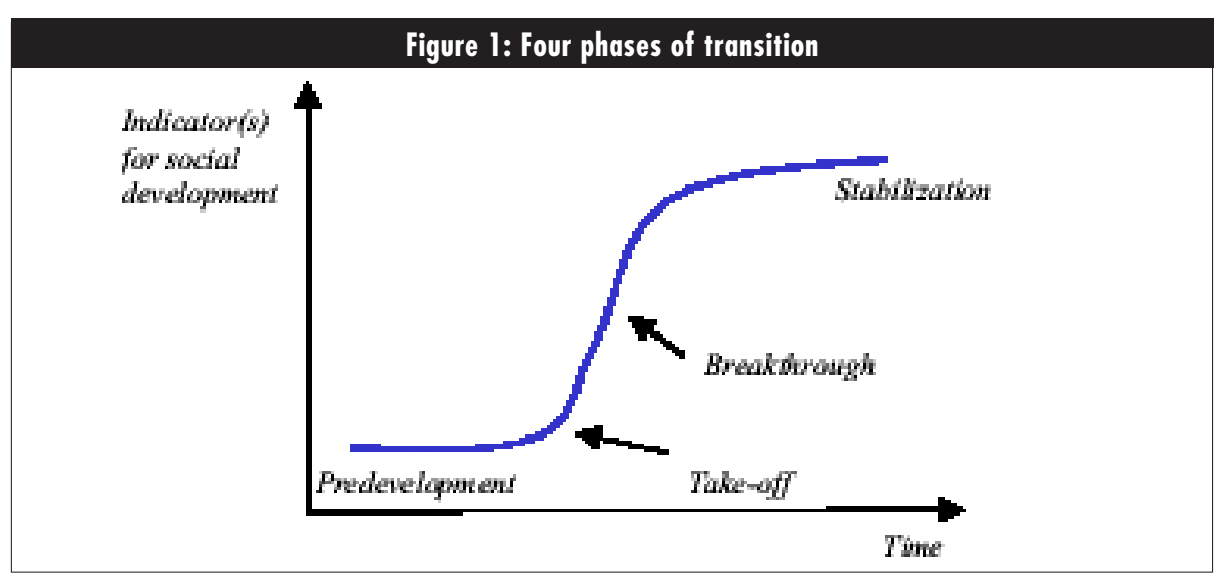

\section{Can transitions be managed?}

It is important to note that in the transition model policy is not viewed an external force but as part of sociotechnical transformations. Policy is the outcome of social interactions over problems and solutions in highly institutionalized settings which can be named policy networks or arenas.

Transitions, however, cannot be managed in a controlling sense. Transitions defy control because they are the outcome of the interplay of many unlike processes, several of which are beyond the scope of control, such as cultural change that can be considered as a sort of autonomous process. Transition management breaks with the old planning and implementation model and has to rely on goal-oriented modulation. Goal-oriented modulation is a more process-oriented steering philosophy where ongoing developments are exploited strategically. This helps to deal with complexity, uncertainty and conflicting interests in a constructive way. Transition management for sustainability tries to orient dynamics to sustainability goals chosen by society, relying on procedural acceptance (5).

Societies' problem-solving capabilities are mobilised and translated into a transition programme, which is legitimised through the political process. Embedding transition goals and policies in institutional arrangements is a key element. Transition management is thus not only concerned with technologies but also with institutional change. It is iterative, forward-looking and adaptive. Learning and innovation are made important goals for policy. The goals are chosen by society but the means and functional systems to meet those goals are not; they are determined in the market place under political frame conditions.

Policy actions are evaluated against two types of criteria: the immediate contribution to policy goals, and the contribution of the policies to the overall transition process. This means that under transition management policies have a content goal and a process goal. The evaluation and adaptation of policies in development rounds brings flexibility to the process without losing a long-term focus.

\section{Changed role of governments}

Transition management is not a total break with past policy. Within transition management there is a need for specialized policies. It puts these policies in a different, longer-term perspective and tries to better align specific policies. Mathematically one could say that transition management equals current policies plus long-term vision plus 
vertical and horizontal coordination of policies plus technology portfolio-management plus process management.

The role of government differs according to the transition phase. For example, in the predevelopment stages there is a special need for social experimentation and creating support for a transition programme, the details of which should evolve with experience. In the breakthrough phase there is a special need for controlling the side effects of large-scale applications of new technologies. Throughout the entire transition the external cost of old and new technologies should be reflected in prices. This is not easy. Taxes are disliked by anyone who has to pay them.

Overall, transition management requires new roles and new modes of operation, especially for governments, that deal with the specific characteristics of transition processes. This means that a policy-transition towards a more flexible, participative and facilitating government is necessary (6).

Transition management opts for an incrementalist strategy for changing functional systems. The reason for this is that you cannot get new technology systems as well as politics right the first time. One has to opt for small steps in what is generally perceived the right direction and to try different solutions. Like politics, technologies are not born perfect but require adaptation before they constitute a good solution and it is best to have a portfolio of options available.

\section{Dutch transition policies}

One of the ministries that adopted transition management was the Ministry of Economic Affairs, responsible for industry and energy. Since 2001, this ministry has been very active in developing transition policies for the transition to a sustainable energy-supply system by 2050 (7). In 2001, the Ministry of Economic Affairs asked consulting companies, researchers and NGOs to assess whether they saw possibilities for the transition, and if so, how likely they considered success. Based on these conversations and an intensive scenario-study, they selected five so called robust elements or subprojects in the transition to a sustainable energy system with a time-horizon of 2030 :

- Biomass International

- New Gas Services

- Sustainable Industrial Production

- Toward a Sustainable Rijnmond (an industrial ecology project)

- Policy Renewal
In 2002, the Ministry started the project Implementation Transition Management that had to investigate whether the selected subprojects would meet enough support, enthusiasm, and commitment from the relevant stakeholders to create a climate in which they would be willing and able to work together. The project was initially financed with 35 million Euros and supported by a staff of eight persons. Main conclusions from this phase were that the transition approach proved to be appealing to the majority of the stakeholders and they would be willing to invest time and money and commit themselves to such a process under the condition that the transition management approach would be made more tangible, that more explicit visions for the future would be developed, and that the government would support the transition endeavour both financially as well as process-wise.

\section{- Green light for Sustainability}

Based on these findings, green light was given for implementation of phase two in 2003. The objectives of this phase were to develop a long-term vision on energy in general and to have each of the subprojects supported by all relevant actors, to have them committed to the process, to map possible paths, barriers and necessary preconditions for the transition, to set up plans for knowledge-development and -sharing and communication, to chart international developments and finally to develop transition-experiments. For biomass, phase two resulted in the vision of 20 to 40 per cent biomass of primary energy supply in 2050. The main transition paths identified are gasification, pyrolysis, and bio-fuels to be adapted with time.

In 2004, 35 million Euro were made available for strategic experiments. Perhaps of greater significance, the Ministry is reconsidering its instruments and interactions with society through the project Policy Renewal. They are opting for a more participatory and interactive type of governance. An example was the establishment of an intervision group for the energy transition, an independent think tank composed mostly of non-energy experts, in January 2004. The public has not been involved in the selection of the transition goals or interim goals. The goals of 20 to 40 per cent biomass have been chosen by business. The government itself selected transition goals of reliability, cost-efficiency and low carbon dioxide emissions.
Transition management is thus having an impact in the Netherlands and also deserves to be considered for policy in other countries, even when it is too early to tell what will come out of it.

\section{Anmerkungen}

(1) Fourth National Environmental Policy Plan (ed.): Een wereld en een wil. Werken aan duurzaamheid. (A World and a Will. Working towards Sustainability), The Hague 2000. (2) Rotmans, J./ Kemp, R./van Asselt, M./ Geels, F./ Verbong, G./ Molendijk, K.: Transities \& Transitiemanagement. De casus van een emissiearme energievoorziening. Final report of the study Transitions and Transition Management for the 4th National Environmental Policy of the Netherlands, Maastricht 2000, p. 19.

(3) The description of transitions and transition management is taken from Rotmans, J./ Kemp, R./ Asselt van M.: More Evolution than Revolution. Transition Management in Public Policy. In: Foresight 3/ 2001, pp. 15-31 and from Kemp, R./ Rotmans, J.: The Management of the Co-Evolution of technical, environmental and social Systems. In: Weber, M./ Hemmelskamp, J. (eds.): Towards environmental Innovation Systems. Berlin and Heidelberg (forthcoming). (4) Geels, F.: Technological transitions as evolutionary reconfiguration processes: A multi-level perspective and a case-study. In: Research Policy, Vol. 31, No. 8/9, 2002 pp. 1257-1274.

(5) Grunwald, A.: Technology Policy between Long-term Planning Requirements and Short-ranged Acceptance Problems. New Challenges for Technology Assessment. In: Grin, J. / Grunwald, A. (eds.): Vision Assessment: Shaping Technology in the 21 st Century Society. Towards a Repertoire for Technology Assessment. Berlin and Heidelberg 2000.

(6) Kemp, R./ Loorbach, D.: Governance for Sustainability through Transition Management. Paper for EAEPE 2003 Conference, Maastricht 2003 Download: http://meritbbs.unimaas.nl/rkemp/Kemp_and_Loorbach.pdf

(7) See www.energietransitie.nl

\section{Der Autor}

Dr. René Kemp arbeitet als Forscher beim Maastricht Economic Research Institute on Innovation and Technology (MERIT) und bei TNO Strategy, Technology and Policy.

Kontakt: MERIT, Maastricht University, P.O. Box 616, 6200 MD Maastricht, Niederlande, E-Mail: r.kemp@merit.unimaas.nl 
(c) 20I0 Authors; licensee IÖW and oekom verlag. This is an article distributed under the terms of the Creative Commons Attribution Non-Commercial No Derivates License (http://creativecommons.org/licenses/by-nc-nd/3.o/), which permits unrestricted use, distribution, and reproduction in any medium, provided the original work is properly cited. 